\title{
Changing prevalence of asthma among schoolchildren in Israel
}

\author{
A.I. Goren, S. Hellmann
}

\begin{abstract}
Changing prevalence of asthma among schoolchildren in Israel. A.I. Goren, S. Hellmann. (C) ERS Journals Ltd 1997.
\end{abstract}

ABSTRACT: This survey was part of a health monitoring system operated in the vicinity of a new power plant in Israel. The aim of this analysis was to determine whether a temporal trend of increased prevalence of asthma can be observed among cohorts of same-aged children, between 1980 and 1989.

Schoolchildren were followed up between 1980 and 1989. They performed pulmonary function tests (PFTs), and their parents filled out American Thoracic Society-National Heart and Lung Institute (ATS-NHLI) health questionnaires. This report deals with the changes in the prevalence of asthma, related respiratory conditions and PFT in four cross-sectional data sets gathered among eighth-grade schoolchildren (aged 13-14 yrs).

A highly significant $(\mathrm{p}=\mathbf{0 . 0 0 0 5})$ increase in the prevalence of asthma (from 5.6\% in 1980 to $11.2 \%$ in 1989), and of wheezing accompanied by shortness of breath $(\mathrm{p}=0.0009)$ could be observed. A similar trend could not be found for the prevalence of bronchitis among these children. PFTs of children suffering from asthma or from wheeze accompanied by shortness of breath were lower than those of healthy children. Changes in prevalence of background variables over time could not explain these findings.

The significant rise in the prevalence of asthma coupled with reduced pulmonary function test results among asthmatic children, seems to reflect a true increase in morbidity. Temporal changes in the prevalence of background variables as well as proximity to the power plant could not explain this trend.

Eur Respir J 1997; 10: 2279-2284.
Institute for Environmental Research, Ministry of the Environment and Sackler School of Medicine, Tel-Aviv University, Tel-Aviv 69978, Israel.

Correspondence: A.I. Goren Institute for Environmental Research Ministry of the Environment Sackler School of Medicine Tel-Aviv University Tel-Aviv 69978

Israel

\section{Keywords: Asthma} pulmonary function tests respiratory symptoms

Received: October 241996 Accepted after revision July 121997

This study was supported by a grant from the Israel Ministry of Health.
The first coal-fired power plant in Israel is located on the coast in a semirural region midway between TelAviv and Haifa. The plant consists of four $350 \mathrm{MW}$ units. The units were gradually put into operation from 1981, until the summer of 1984, by which time all were operating. The permit to build and operate this power plant included the proviso that three monitoring systems (environmental, agricultural and long-term health monitoring) be set up near the plant. The health monitoring programme [1] included four health surveys: mortality; requests for health services; health of schoolchildren; and an adult panel. The aim of this monitoring programme was to carry out a spatiotemporal follow-up of the health status of the population residing in the vicinity of the power plant, in order to detect any deterioration in their health attributable to the operation of the plant.

Reports of a temporal increase in the prevalence of asthma in Israel [2-3] and elsewhere [4-14] motivated us to determine whether a temporal trend of increased prevalence of asthma and related symptoms can be observed among cohorts of same-aged schoolchildren studied in the four cross-sectional surveys, between 1980 and 1989.

\section{Subjects and methods}

A follow-up was regularly conducted among second-, fifth- and eighth-grade (8, 11 and 14 yr old) pupils, liv- ing in three communities located within $19 \mathrm{~km}$ of the power plant (fig. 1). According to the Environmental Impact Statement prepared by the Israel Electric Company [15], differing extents of pollution were expected in these communities as a result of the operation of the power plant.

Baseline data for this study were gathered in 1980, before the first unit was put into operation. The second data set was gathered in 1983 when two units of the plant were operating, and the third and fourth sets were gathered in 1986 and 1989 when all units were operating. The health questionnaire used in this survey was a translated version of the American Thoracic SocietyNational Heart and Lung Institute (ATS-NHLI) selfadministered questionnaire [16] to be completed by the children's parents. The questionnaires included information on respiratory symptoms and diseases of the studied children and their parents, as well as socioeconomic information. They were distributed to the children by the school nurses who also collected them after completion. After receiving these questionnaires, the survey technician conducted pulmonary function tests (PFTs) in the participating schools using a portable spirometer (AS-1000; Minato Medical Science Co. Ltd, Osaka, Japan).

The PFT parameters obtained were forced vital capacity (FVC), forced expiratory volume in one second (FEV1), 
and FEV1/FVC. The pupils performed the test standing and repeated the manoeuvre (without a noseclip) at least three times until two similar tests (within 10\%) were obtained. The best test (highest FVC+FEV1) was chosen. In each round the same technician carried out the PFTs in all the participating schools. The school nurses weighed the children and measured their height. All tests were done between April and June during the morning hours. Statistical analysis was carried out using Statistical Products and Service Solutions (SPSS; Chicago, USA) and BioMedical Program (BMDP; University of California, Berkeley, CA, USA) programs [17, 18].

Prevalence of respiratory symptoms and diseases among children from the four different cohorts, were analysed by means of Chi-square test for trend. Chi-square trend analysis was also carried out for background variables. In order to examine the combined effect of background variables on respiratory conditions, logistic regressions were fitted for the prevalence of asthma and related respiratory symptoms in each cohort. The independent variables included in the regressions were: respiratory diseases among parents; parent's education; mothers' smoking; household heating; crowding index; and residential area. Those background variables that were included in the logistic regressions for each cohort, the year of study and the relevant interactions were included in the logistic models fitted for the respiratory conditions in the pooled data set of the four cohorts. The criteria for inclusion of a variable in the model were: $p$-value to remove $>0.15$; and $p$-value to enter $<0.10$. The environmental monitoring network (fig. 1) consisted of 12 monitoring stations, of which 10 were stationary and two were

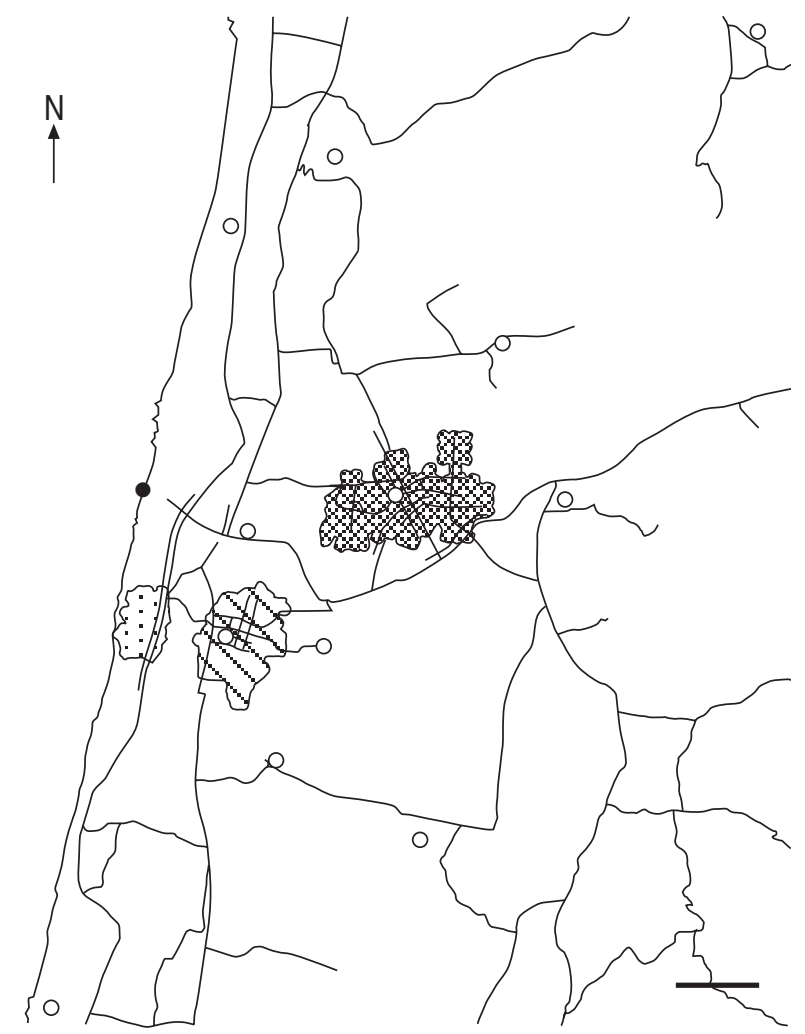

Fig. 1. - Expected levels of pollution in three communities, and the location of the power station $(\bullet)$ and monitoring stations $(\bigcirc) . \cdot \square$ : low pollution; $:$ medium pollution; $\boldsymbol{Q}$ : high pollution. Internal scale bar $=2 \mathrm{~km}$. mobile. The stations were fully automatic and measured $\mathrm{SO}_{2}, \mathrm{NO}_{\mathrm{x}}, \mathrm{O}_{3}, \mathrm{CO}$, total hydrocarbons, and meteorological parameters. Not all monitoring stations performed all measurements. The instruments were calibrated automatically and measured the levels of ambient air pollution continuously. The data were sent by radio to the Association of Towns and fed into a computer that stored and analysed them.

Because of the difficulty of following trends of such low levels of annual average concentrations over several years, we decided to focus on half-hourly concentrations, for which there is also an Israeli ambient standard. We counted the number of air pollution "events" in which the half-hourly averages for $\mathrm{SO}_{2}$ or $\mathrm{NO}_{x}$ were above an arbitrary threshold. The threshold values chosen were $183 \mu \mathrm{g} \cdot \mathrm{m}^{-3}$ (70 parts per billion (ppb)) for $\mathrm{SO}_{2}$ and $235 \mu \mathrm{g} \cdot \mathrm{m}^{-3}$ (125 ppb) for $\mathrm{NO}_{\mathrm{x}}$, which are about $25 \%$ of the local air quality standards and about $12 \%$ of the Israeli air quality standards.

\section{Results}

The study population in the four rounds of examinations by year and gender is described in table 1. A somewhat higher percentage of girls was observed during the study years, with no significant change in their representation in the different cohorts. The response rate for filling out the health questionnaires ranged 70-90\%.

The prevalence of diagnosed asthma and of wheeze accompanied by shortness of breath among all eighthgrade schoolchildren from the four cohorts is presented in figure 2. A highly significant gradual increase in the prevalence of both asthma (ever) and wheeze (ever) characterized subjects in the eighth grade throughout the 1980-1989 cohorts. As can be seen in figure 3, the prevalence of bronchitis (ever) barely changed over this

Table 1. - Study population by year and gender

\begin{tabular}{lcccc}
\hline & \multicolumn{4}{c}{ Year } \\
\cline { 2 - 5 } & 1980 & 1983 & 1986 & 1989 \\
\hline Males & $319(43.3)$ & $311(44.5)$ & $471(47.4)$ & $448(46.5)$ \\
Females & $418(56.7)$ & $387(55.5)$ & $522(52.6)$ & $515(53.5)$ \\
Total & 737 & 698 & 993 & 963 \\
\hline
\end{tabular}

Values are absolute numbers, and percentages in parentheses

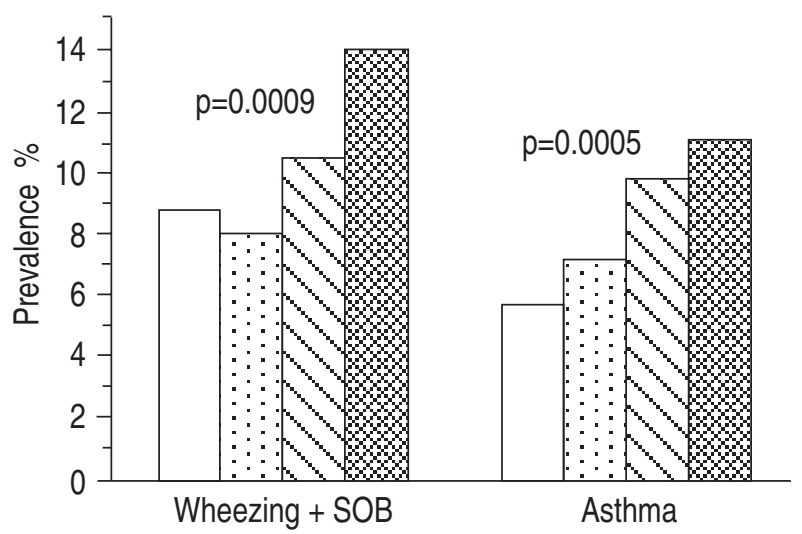

Fig.2. - Prevalence of asthma and wheezing with shortness of breath (SOB) among eighth-grade children. $\square: 1980 ; \square: 1983$; $\square: 1986$; 《: 1989. 


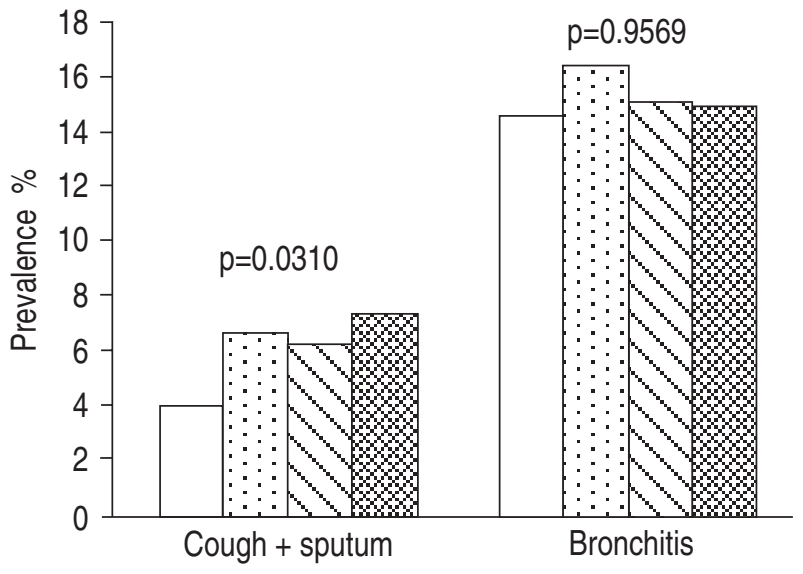

Fig. 3. - Prevalence of bronchitis and cough with sputum among eighth-grade children. $\square$ : 1980; $\square: 1983$; $\square$ : 1986; \&: 1989.

time, while the prevalence of cough accompanied by sputum increased in the cohorts studied from 1980 to 1989.

The prevalence of background variables in the different cohorts, among unaffected (healthy) and affected (suffering from asthma or wheezing with shortness of breath) children is presented in table 2 . This analysis was carried out in order to determine whether a temporal trend in the prevalence of risk factors could explain the significant rise in asthma and wheezing between 1980 and 1989. The temporal changes in the studied risk factors could not have been responsible for the observed changes in the prevalence of asthma over time (table 2).

A substantial decrease in the prevalence of crowded homes $\left(>1.5\right.$ persons $\cdot$ room $\left.^{-1}\right)$ characterized both healthy and asthmatic children. Similarly, a significant decrease in the number of homes heated by kerosene or gas was observed. A substantial temporal rise in the prevalence of mothers with higher education ( $\geq 13 \mathrm{yrs}$ ) could be observed both among asthmatic and healthy children.

A trend of increased prevalence of (ever) smoking mothers among both healthy and asthmatic children could be observed. No significant change in the prevalence of diagnosed asthma (ever) or bronchitis among the parents of both asthmatic and healthy children was observed.
Comparing the prevalence of risk factors among healthy and asthmatic children shows that asthmatic children did not grow up in more crowded homes than healthy children. No major differences could be observed in the prevalence of mothers' education or mothers' smoking while comparing healthy and asthmatic children. However, the rate of respiratory diseases among the parents of asthmatics was roughly 2-3 times that among the parents of healthy children.

Logistic regressions enabled examination of the combined effect of the background variables on the prevalence of asthma and wheezing in each year of study (cohort).

In the models fitted for asthma in each of the four rounds of study, respiratory diseases among parents was a significant factor (OR 3.00). Further significant variables in these models were: residential area in 1986 (OR $=1.42$ for the expected polluted area) and mothers' smoking in 1989 (OR = 1.67). Therefore, the independent variables taken into account in the asthma model fitted for the pooled data set were: year of study, residential area, mothers' smoking, parents' respiratory diseases and the relevant interactions.

In the models fitted for wheezing accompanied by shortness of breath in three out of four rounds of study, respiratory diseases among parents was a significant factor $(\mathrm{OR}=2.11-4.34)$. No further significant variables were included in these models. The independent variables taken into account in the wheezing-model fitted for the pooled data set were: year of study, parents' respiratory diseases and the relevant interactions.

The odds ratio (OR) values for asthma and wheezing as calculated from logistic models for the pooled data are presented in table 3 . Only the statistically significant variables included in the models are shown. The model describing the prevalence of asthma includes the year of study as a significant factor, indicating a gradual increased risk to suffer from asthma. The same holds for the model built for wheezing accompanied by shortness of breath. Both the model for asthma and that for wheezing include, as a very significant explanatory factor, a history of respiratory diseases among the parents of the children. However, this risk factor does not affect the changing prevalence rates of asthma and wheezing across the studied years.

Table 2. - Prevalence of background variables for eighth-grade healthy and asthmatic children in four cohorts in Hadera, Israel

\begin{tabular}{|c|c|c|c|c|c|c|c|c|c|c|}
\hline & \multicolumn{8}{|c|}{ Prevalence $\%$} & \multirow{2}{*}{\multicolumn{2}{|c|}{$\begin{array}{l}\mathrm{p} \text {-value } \\
\text { for trend }\end{array}$}} \\
\hline & \multicolumn{2}{|c|}{1980} & \multicolumn{2}{|c|}{1983} & \multicolumn{2}{|c|}{1986} & \multicolumn{2}{|c|}{1989} & & \\
\hline & $\mathrm{H}$ & A & $\mathrm{H}$ & A & $\mathrm{H}$ & A & $\mathrm{H}$ & A & $\mathrm{H}$ & A \\
\hline Crowded homes & $\begin{array}{l}44.5 \\
(411)\end{array}$ & $\begin{array}{l}46.0 \\
(50)\end{array}$ & $\begin{array}{l}40.0 \\
(417)\end{array}$ & $\begin{array}{l}30.8 \\
(52)\end{array}$ & $\begin{array}{l}39.6 \\
(570)\end{array}$ & $\begin{array}{l}39.2 \\
(102)\end{array}$ & $\begin{array}{l}32.8 \\
(463)\end{array}$ & $\begin{array}{l}29.0 \\
(107)\end{array}$ & 0.0007 & 0.0934 \\
\hline $\begin{array}{l}\text { Heating } \\
\text { (kerosene or gas) }\end{array}$ & $\begin{array}{c}48.1 \\
(424)\end{array}$ & $\begin{array}{l}59.6 \\
(52)\end{array}$ & $\begin{array}{l}47.7 \\
(426)\end{array}$ & $\begin{array}{l}49.1 \\
(55)\end{array}$ & $\begin{array}{c}42.4 \\
(576)\end{array}$ & $\begin{array}{c}40.8 \\
(103)\end{array}$ & $\begin{array}{c}37.7 \\
(475)\end{array}$ & $\begin{array}{l}42.9 \\
(112)\end{array}$ & 0.0004 & 0.0428 \\
\hline $\begin{array}{l}\text { Father with higher } \\
\text { education ( } \geq 13 \text { yrs) }\end{array}$ & $\begin{array}{l}18.4 \\
(424)\end{array}$ & $\begin{array}{l}19.2 \\
(52)\end{array}$ & $\begin{array}{l}22.9 \\
(428)\end{array}$ & $\begin{array}{l}12.7 \\
(55)\end{array}$ & $\begin{array}{c}22.6 \\
(575)\end{array}$ & $\begin{array}{l}19.6 \\
(102)\end{array}$ & $\begin{array}{c}25.0 \\
(476)\end{array}$ & $\begin{array}{l}25.2 \\
(111)\end{array}$ & 0.0276 & 0.1636 \\
\hline $\begin{array}{l}\text { Mother with higher } \\
\text { education ( } \geq 13 \text { yrs) }\end{array}$ & $\begin{array}{l}19.8 \\
(424)\end{array}$ & $\begin{array}{l}21.2 \\
(52)\end{array}$ & $\begin{array}{l}28.0 \\
(428)\end{array}$ & $\begin{array}{l}21.8 \\
(55)\end{array}$ & $\begin{array}{l}22.9 \\
(576)\end{array}$ & $\begin{array}{l}21.4 \\
(103)\end{array}$ & $\begin{array}{l}29.0 \\
(476)\end{array}$ & $\begin{array}{l}33.0 \\
(112)\end{array}$ & 0.0169 & 0.0738 \\
\hline Smoking mother & $\begin{array}{l}21.2 \\
(415)\end{array}$ & $\begin{array}{l}27.5 \\
(51)\end{array}$ & $\begin{array}{l}24.6 \\
(418)\end{array}$ & $\begin{array}{l}23.1 \\
(52)\end{array}$ & $\begin{array}{l}28.7 \\
(561)\end{array}$ & $\begin{array}{l}36.0 \\
(100)\end{array}$ & $\begin{array}{l}28.3 \\
(473)\end{array}$ & $\begin{array}{l}29.6 \\
(108)\end{array}$ & 0.0062 & 0.4971 \\
\hline $\begin{array}{l}\text { One parent with } \\
\text { respiratory disease }\end{array}$ & $\begin{array}{l}13.7 \\
(373)\end{array}$ & $\begin{array}{l}27.3 \\
(44)\end{array}$ & $\begin{array}{l}19.0 \\
(385)\end{array}$ & $\begin{array}{l}40.4 \\
(47)\end{array}$ & $\begin{array}{l}12.9 \\
(519)\end{array}$ & $\begin{array}{l}38.1 \\
(84)\end{array}$ & $\begin{array}{l}12.7 \\
(442)\end{array}$ & $\begin{array}{l}28.4 \\
(95)\end{array}$ & 0.2073 & 0.7493 \\
\hline
\end{tabular}

Values in parentheses are the number of subjects. H: healthy subjects; A: subjects with asthma or shortness of breath. 
Table 3. - Odds ratios (ORs) for respiratory conditions among eighth-grade schoolchildren as related to background variables and year of study (calculated from logistic models)

\begin{tabular}{|c|c|c|c|}
\hline $\begin{array}{l}\text { Statistically significant } \\
\text { variables }\end{array}$ & OR & $95 \% \mathrm{CI}$ & $\begin{array}{l}\text { Goodness } \\
\text { of fit }\end{array}$ \\
\hline \multicolumn{4}{|l|}{ Asthma } \\
\hline \multicolumn{4}{|l|}{ Year of study } \\
\hline 1980 & 1.00 & & \\
\hline 1983 & 0.91 & $0.49-1.69$ & \\
\hline 1986 & 1.40 & $0.82-2.39$ & \\
\hline 1989 & 1.87 & $1.11-3.16$ & \\
\hline \multicolumn{3}{|l|}{ Respiratory diseases } & $p=0.499$ \\
\hline \multicolumn{4}{|c|}{ Wheezing with shortness of breath } \\
\hline \multicolumn{4}{|c|}{ Year of study } \\
\hline 1980 & 1.00 & & \\
\hline 1983 & 0.70 & $0.41-1.19$ & \\
\hline 1986 & 1.06 & $0.68-1.66$ & \\
\hline 1989 & 1.59 & $1.03-2.45$ & \\
\hline $\begin{array}{l}\text { Respiratory diseases } \\
\text { of parents }\end{array}$ & 3.10 & $2.17-4.43$ & $\mathrm{p}=0.279$ \\
\hline
\end{tabular}

95\% CI: $95 \%$ confidence interval.

The models for asthma $(\mathrm{p}=0.499)$ and for wheezing $(\mathrm{p}=0.279)$ fit the data quite well, i.e. there is a relatively small discrepancy between the observed and the predicted values.

Pulmonary function tests (FEV1, FEV1/FVC) for healthy and asthmatic children in the four cohorts are presented in table 4. The aim of this analysis was to find out whether PFTs of asthmatic and wheezing children were lower than those of healthy children in the four surveys. Part of the PFTs were significantly lower among children suffering from asthma compared with healthy children. For children reporting wheezing accompanied by shortness of breath most PFTs were significantly lower compared to those of healthy children. No such trend was observed among children for whom bronchitis or related symptoms (such as cough accompanied by sputum) were reported.
During the time period of the study, the ambient air pollution levels did not exceed the Israeli air quality standards or the more stringent local standards (half of the Israeli standard), based on measurements of $\mathrm{SO}_{2}$ and $\mathrm{NO}_{\mathrm{x}}$, at the 12 monitoring stations (fig. 1). In fact, the annual average $\mathrm{SO}_{2}$ and $\mathrm{NO}_{\mathrm{x}}$ values were very low. For instance, the 1989 annual $\mathrm{SO}_{2}$ average did not exceed $20 \mu \mathrm{g} \cdot \mathrm{m}^{-3}$, less than $25 \%$ of the US standard, at any monitoring station.

The monitoring stations recorded an increase in the total number of "events" for $\mathrm{SO}_{2}$ and for $\mathrm{NO}_{\mathrm{x}}$ during 1981-1992. Part of the increase in the number of "events" originated from the operation of the power plant, but the main increase was connected with other sources, such as industry and especially traffic. The sources responsible for the events were identified according to the wind direction measured at the time. The highest number of $\mathrm{SO}_{2}$ events from the power plant was measured at the monitoring station located in the area expected to be most polluted (fig. 4); a markedly lower number

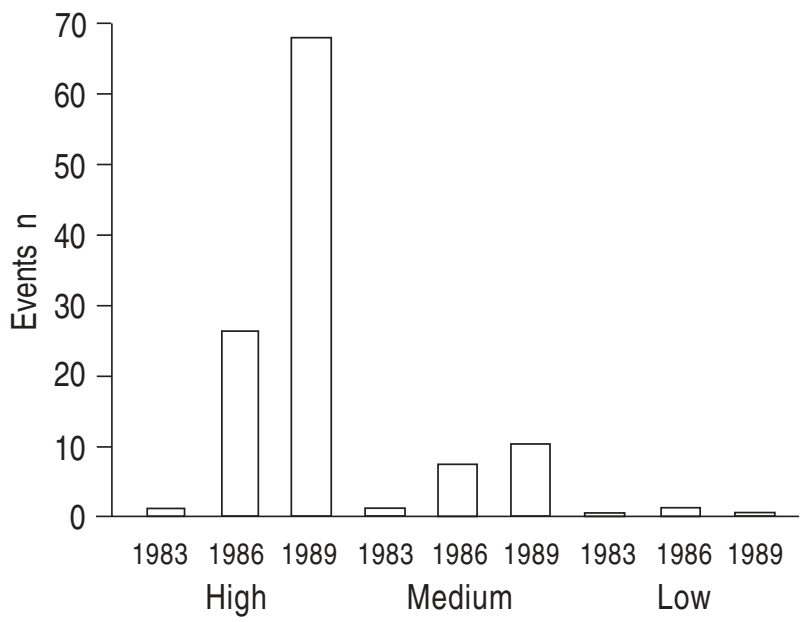

Fig. 4. - Sulphur dioxide pollution events from the power station in expected low, medium and high pollution areas in 1983, 1986 and 1989.

Table 4. - Pulmonary function test (PFT) results among eighth-grade healthy and asthmatic children in four cohorts in Hadera, Israel

\begin{tabular}{|c|c|c|c|c|c|c|c|}
\hline \multirow[t]{2}{*}{ Year } & \multirow[t]{2}{*}{ PFT } & \multicolumn{3}{|c|}{ Wheezing with shortness of breath } & \multicolumn{3}{|c|}{ Asthma } \\
\hline & & $\mathrm{H}$ & A & p-value & $\mathrm{H}$ & A & p-value \\
\hline \multirow[t]{2}{*}{1980} & FEV1 $\%$ pred & $\begin{array}{c}99.47 \pm 13.99 \\
(488)\end{array}$ & $\begin{array}{c}98.42 \pm 19.04 \\
(46)\end{array}$ & 0.6393 & $\begin{array}{l}99.52 \pm 14.37 \\
(443)\end{array}$ & $\begin{array}{c}95.15 \pm 19.68 \\
(27)\end{array}$ & 0.1350 \\
\hline & FEV1/FVC $\%$ & $\begin{array}{c}89.26 \pm 9.02 \\
(489)\end{array}$ & $\begin{array}{c}86.14 \pm 12.12 \\
(47)\end{array}$ & 0.0292 & $\begin{array}{c}88.94 \pm 9.34 \\
(445)\end{array}$ & $\begin{array}{c}86.06 \pm 12.41 \\
\text { (27) }\end{array}$ & 0.1282 \\
\hline \multirow[t]{2}{*}{1983} & FEV1 \% pred & $\begin{array}{c}94.72 \pm 15.80 \\
(489)\end{array}$ & $\begin{array}{c}87.69 \pm 13.75 \\
(43)\end{array}$ & 0.0049 & $\begin{array}{c}94.13 \pm 14.47 \\
(446)\end{array}$ & $\begin{array}{c}94.48 \pm 20.46 \\
(35)\end{array}$ & 0.8947 \\
\hline & $\mathrm{FEV} 1 / \mathrm{FVC} \%$ & $\begin{array}{c}90.01 \pm 7.89 \\
(489)\end{array}$ & $\begin{array}{c}86.26 \pm 8.20 \\
(43)\end{array}$ & 0.0030 & $\begin{array}{c}89.89 \pm 7.99 \\
(446)\end{array}$ & $\begin{array}{c}87.72 \pm 9.28 \\
(35)\end{array}$ & 0.1261 \\
\hline \multirow[t]{2}{*}{1986} & FEV1 \% pred & $\begin{array}{c}90.89 \pm 11.52 \\
(678)\end{array}$ & $\begin{array}{c}89.07 \pm 11.68 \\
(79)\end{array}$ & 0.1857 & $\begin{array}{c}90.90 \pm 11.45 \\
(601)\end{array}$ & $\begin{array}{c}87.74 \pm 10.98 \\
(66)\end{array}$ & 0.0334 \\
\hline & FEV1/FVC \% & $\begin{array}{c}90.24 \pm 6.80 \\
(679)\end{array}$ & $\begin{array}{c}86.10 \pm 8.04 \\
(79)\end{array}$ & $<0.0001$ & $\begin{array}{c}90.14 \pm 6.26 \\
(602)\end{array}$ & $\begin{array}{c}86.03 \pm 7.60 \\
(66)\end{array}$ & $<0.0001$ \\
\hline \multirow[t]{2}{*}{1989} & FEV1 $\%$ pred & $\begin{array}{c}99.45 \pm 12.42 \\
(530)\end{array}$ & $\begin{array}{c}94.68 \pm 12.11 \\
(85)\end{array}$ & 0.0010 & $\begin{array}{c}99.25 \pm 12.36 \\
(505)\end{array}$ & $\begin{array}{c}94.76 \pm 13.03 \\
(64)\end{array}$ & 0.0067 \\
\hline & FEV1/FVC \% & $\begin{array}{c}90.40 \pm 6.49 \\
(530)\end{array}$ & $\begin{array}{c}87.40 \pm 7.83 \\
(85)\end{array}$ & 0.0001 & $\begin{array}{c}90.52 \pm 6.46 \\
(505)\end{array}$ & $\begin{array}{c}86.96 \pm 8.19 \\
(64)\end{array}$ & 0.0001 \\
\hline
\end{tabular}

Values are presented as mean \pm SD, and number of subjects in parenthesis. PFT: pulmonary function test; H: healthy subjects; A: subjects with asthma or shortness of breath; \% pred: percentage of predicted value; FEV1: forced expiratory volume in one second; FVC: forced vital capacity. 
was registered in the area expected to be moderately polluted and almost no events in the monitoring station located in the expected low-pollution area.

\section{Discussion}

In common with other studies [2-14], we demonstrated a significant increase in the prevalence of asthma and wheezing accompanied by shortness of breath in the four cross-sectional data sets. FLEMING and CROMBIE [4], who compared the prevalence of asthma in general practices during 1981-1982 to that during 1970-1971, found a statistically significant increase in asthma morbidity in England and in Wales. BuRnEy et al. [5] estimated changes in the prevalence of reported respiratory symptoms, asthma and bronchitis in primary school children in England during 1973-1986. They found significant trends of increasing prevalence of asthma and wheeze for each annual birth cohort studied. BURR and co-workers [6,9] conducted two surveys 15 yrs apart, among children aged 12 yrs in South Wales. Similar to our findings, an increase in the prevalence of wheeze from $17-22 \%$ and an increase in history of asthma from 6$12 \%$ was observed. Exercise provocation tests suggested that both mild and severe asthma had become more common.

NINAN and RUSSELL [7] studied the prevalence of asthma-related symptoms and atopy in Aberdeen schoolchildren. The prevalence of wheeze rose from $10.4 \%$ in 1964 to $19.8 \%$ in 1989, episodes of shortness of breath increased from $5.4 \%$ to $10.0 \%$ and the reported diagnosis of asthma rose from $4.1 \%$ to $10.2 \%$. Reported asthma among children aged 6-11 yrs in the USA [8], showed a significant increase from $4.8 \%(1971-1974)$ to $7.6 \%$ (1976-1980).

PEAT et al. [10] report an increased prevalence of wheeze (in the previous 12 months) among Australian schoolchildren between 1982 (10.4\%) and 1992 (27.6\%). ROBERTSON et al. [11] report an increase of $141 \%$ in the prevalence of a history of asthma among $7 \mathrm{yr}$ old children in Melbourne between 1964 (19.1\%) and 1990 (46\%). SHAw et al. [12] studied adolescent schoolchildren in a rural area in New Zealand and found that the prevalence of reported asthma or wheeze significantly increased from $26.2 \%$ in 1975 to $34.0 \%$ in 1989 .

Two Israeli groups [2, 3] studied young Israeli adults at the age of 17-18 yrs, undergoing medical examinations $1 \mathrm{yr}$ before military service and found a significant increase in the prevalence of asthma during the last decade 1980-1990.

In common with the above-cited studies, we found a significant increase in the prevalence of asthma, from $5.7 \%$ in 1980 to $11.2 \%$ in 1989 , as well as a rise in the prevalence of wheezing accompanied by shortness of breath from $8.8 \%$ to $14.1 \%$. The increase in the prevalence of asthma in all of these studies suggests that there has been a true increase in morbidity that is not simply due to changes in diagnostic fashion. We tried to find out whether elevated exposure to various risk factors among the studied children could explain this significant rise in the prevalence of asthma and related symptoms.

These increased rates cannot be explained by unfavourable temporal changes in socioeconomic factors among asthmatic children, such as changes in family size, which could have an effect on respiratory infections in early life. Trends over time in the prevalence of crowding, parents' education and domestic heating (by kerosene or gas) did not differ between asthmatic and healthy children. Although asthmatic children have, to an extent, received greater exposure to smoking mothers, and their parents had significantly more histories of respiratory diseases as compared to healthy children, no significant changes in the prevalence of smoking and of respiratory diseases among their parents occurred between 1980 and 1989. Hence, higher exposure to smoking mothers (though known to predispose to respiratory illness [1922]) and more frequent history of respiratory diseases among parents of asthmatic children (which could be connected with over-reporting $[19,23])$ do not seem to be responsible for the rise in the prevalence of asthma between 1980 and 1989 .

Moreover, logistic regressions, which included risk factors such as socioeconomic variables, exposure to passive smoke, history of parental respiratory diseases and residential area, showed only a significant effect of the year of study with a gradual increase in the risk for asthma during 1980-1989, with a constant elevated risk related to respiratory diseases among parents. No further significant explanatory risk factor for increased asthma was included in the logistic regressions.

In the four studied cohorts, the poorer PFT results that characterized asthmatic or wheezing children, compared to those of healthy ones, suggest that the reporting of asthma is reliable and not due to changes in diagnostic procedures.

The fact that the trend for a rise in the prevalence of asthma was not related to any residential area, that air pollution levels measured in the environmental monitoring network were very low and that no other health study carried out around the power plant found any deleterious health effect [24], strengthen the hypothesis that this rise in reported asthma is apparently not connected with the operation of the power plant, but corresponds to a general trend similar to other findings in Israel [2, $3]$ and elsewhere [4-14].

The reason for this increase in asthma and related symptoms is not clear from this study; it could be due to changes in life style or diet and to increased allergen exposure, subjects that were not covered in our study.

Acknowledgements: The authors wish to thank the Association of Towns for Environmental Protection for their co-operation and the continuous supply of data from the monitoring system.

\section{References}

1. Toeplitz R, Goren A, Goldsmith JR. Epidemiological monitoring in the vicinity of a coal fired power plant. Sci Total Environ 1984; 32: 233-246.

2. Kark JD, Kedem R, Revach M. Medical examination of Israeli 17-years-old before military service as a national resource for health information. Isr J Med Sci 1986; 22 : 318-325.

3. Sacher Y, Danon YL. Longitudinal study on the prevalence of asthma among young adults. Isr J Med Sci 1994; 30: 564-572. 
4. Fleming DM, Crombie DL. Prevalence of asthma and hay fever in England and Wales. BMJ 1987; 294: 279-283.

5. Burney PGJ, Chinn S, Rona RJ. Has the prevalence of asthma increased in children? Evidence from the national study of health and growth 1973-86. BMJ 1990; 300: 1306-1310.

6. Burr ML, Butland BK, King S, Vaughan-Williams E. Changes in asthma prevalence: two surveys 15 years apart. Arch Dis Child 1989; 64: 1452-1456.

7. Ninan TK, Russell G. Respiratory symptoms and atopy in Aberdeen schoolchildren: evidence from two surveys 25 years apart. BMJ 1992; 304: 873-875.

8. Gergen PJ, Mullally DI, Evans R. National survey of prevalence of asthma among children in the United States, 1976 to 1980. Pediatr 1988; 81: 1-7.

9. Burr ML. Is asthma increasing? J Epidem Comm Health 1987; 41: 185-189.

10. Peat JK, van den Berg RH, Green WF, Mellis CM, Leeder SR, Woolcock AJ. Changing prevalence of asthma in Australian children. BMJ 1994; 308: 1591-1596.

11. Robertson CF, Heycock E, Bishop J, Nolan T, Olinsky A, Phelan PD. Prevalence of asthma in Melbourne schoolchildren: changes over 26 years. BMJ 1991; 302: 1116 1118.

12. Shaw RA, Crane J, O'Donnell TV, Porteous LE, Coleman ED. Increasing asthma prevalence in a rural New Zealand adolescent population: 1975-89. Arch Dis Child 1990; 65: 1319-1323.

13. Lundback B, Nystrom L, Rosenhall L, Stjernberg N. Obstructive lung disease in northern Sweden: respiratory symptoms assessed in a postal survey. Eur Respir $J$ 1991; 4: 257-266.

14. Norrman E, Rosenhall L, Nystrom L, Bergstrom E, Stjernberg N. High prevalence of asthma and related symptoms in teenagers in Northern Sweden. Eur Respir $J$ 1993; 6: 834-839.

15. Environmental Impact Statement of the Mem-Dalet (Sharonim) Electric Power Plant. Israel Electric Power Corporation, Haifa, May 1976.

16. Ferris BG. Epidemiology standardization project. Am Rev Respir Dis 1978; 188: 1-120.

17. Nie NH, Hull CH, Jenkins JG, Steinbrenner K, Bent DH. SPSS Statistical Package for the Social Sciences, 2nd Edn. New York, McGraw Hill, 1975.

18. Dixon WJ, Brown MB, Engelman L, et al. BMDP Statistical Software. Berkeley, CA, University of California Press, 1981.

19. Goren A, Goldsmith JR. Epidemiology of childhood respiratory disease in Israel. Eur J Epidemiol 1986; 2: 139-150.

20. Yue C, Wanxian L, Shunzhang Y, Wanhua Q. ChangNing epidemiological study of children's health: I: Passive smoking and children's respiratory diseases. Int J Epidemiol 1988; 17: 348-355.

21. Tager IB, Weiss ST, Munoz A, Rosner B, Speizer FE. Longitudinal study of the effects of maternal smoking on pulmonary function in children. N Engl J Med 1983; 309: 699-703.

22. Goren AI, Hellmann S. Passive smoking among schoolchildren in Israel. Environ Health Perspect 1991; 96: 203-211.

23. Schenker MB, Samet JM, Speizer FE. Risk factors for childhood respiratory disease. Am Rev Respir Dis 1983; 28: 1038-1043.

24. Goren AI, Hellmann S, Glaser ED. Use of outpatient clinics as a health indicator for communities around a coal-fired power plant. Environ Health Perspect 1995; 103: $1110-1115$. 